\title{
De eerste stap
}

$\mathrm{Al}$ jarenlang is Maria bekend in de ggz. Ze kent alle vaktermen en met een dik pakket aan voorinformatie en diagnoses is zij met haar gezin aangemeld bij het MST-CAN behandelprogramma. $\mathrm{Bij}$ ons eerste gesprek ontvangt Maria mij met open armen, maar ze is hopeloos: 'ik hoop echt dat jullie ons kunnen helpen, want het is niet te doen hier thuis'. Dat dit geen understatement is, zie ik al gauw. Het huis is klein, donker en het ruikt er niet fris. Ik zie een viezige bak met een hamster in de hoek staan. De verwijzing? Maria komt een paar jaar niet meer buiten vanwege angsten, depressie. Haar 11-jarige zoon Silas doet vrijwel alle huishoudelijke taken, zoals boodschappen en schoonmaken. De rollen zijn omgedraaid.

De eerste sessies zijn moeilijk te structureren, want het gesprek schiet alle kanten op en Maria's emoties nemen vaak de overhand. Stap 1: we gaan na wat Maria's gewenste behandeluitkomsten zijn. Ze wil hulp bij haar depressies, angsten en lichamelijke klachten, maar natuurlijk ook bij de opvoeding van Silas.

Echter, het vertrouwen is er niet. Door de jaren heen heeft zij veel diagnoses gekregen waardoor zij in een negatieve spiraal terecht is gekomen. Hoewel ik er soms wel vier of vijf keer per week ben om aan Maria's bovengenoemde doelen te werken, speelt er gewoon teveel! Het lukt mij maar niet om de juiste focus te vinden. Ook uit onze 'fit-cirkels' wordt niet duidelijk welke factoren we moeten prioriteren.

Gelukkig gaat Maria akkoord met een consult bij de psychiater van het team. Samen met de psychiater komen we tot een voor Maria verrassende conclusie: ze

\section{'Hartver-}

\section{warmend}

om zo'n compliment te krijgen"

lijdt aan een vermijdende persoonlijkheidsstoornis. $\mathrm{Na}$ een aantal gesprekken waarin psychoeducatie over angst en vermijding centraal staat, komt er een rust over Maria heen. En voor het eerst kan ze echt iets met haar diagnose. Door de belofte om samen stap voor stap met haar angsten aan de slag te gaan, kreeg ze hoop op verandering. Wat voor haar nog belangrijker was

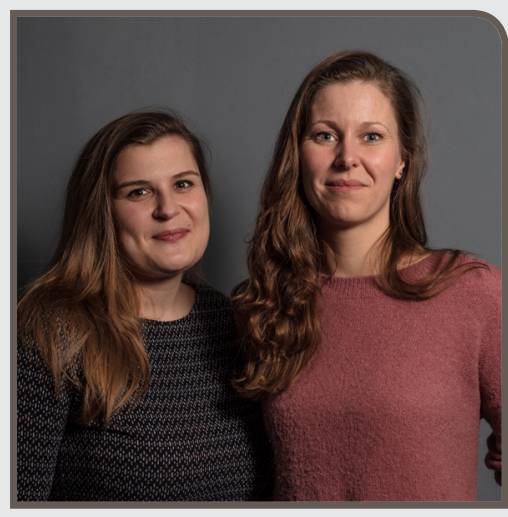

om aan haar eigen verandering te werken, was het inzicht dat haar zoon ook onder de huidige situatie lijdt.

We willen haar weer naar buiten te krijgen en gaan goed voorbereid voor het eerst sinds jaren samen een stukje door Hilversum in lopen. Zij heeft hierin de regie. Ondanks dat Maria super gespannen is, kiest zij zelf een plekje in het park uit om te gaan zitten. Dat gaat goed, we zitten er zelfs twintig minuten! Dit was een van de stappen die hielpen om de negatieve spiraal van Maria te doorbreken.

Tijdens de tweede helft van de behandeling melden we Maria aan voor een individueel psychotherapeutisch traject, wat nu mogelijk is omdat ze in staat is de deur uit te komen. Haar zoontje Silas melden we aan bij een KOPP-groep.

Inmiddels is de behandeling afgesloten en kan Maria nog gerichter aan de slag met zichzelf. Ze komt weer buiten en pakt meer en meer haar rol als moeder op. Ook met Silas gaat het goed, hij kan weer kind zijn. Bij de eindevaluatie had Maria, als dank aan ons, een heleboel tapas gemaakt en we mochten niet vertrekken voordat het op was. Het was hartverwarmend om zo'n mooi compliment van haar te krijgen. 